\title{
Root system architecture and seed weight relations in forage pea (Pisum sativum ssp. arvense L. Poir.)
}

\section{Semih Acikbas ${ }^{*}$ (i) Mehmet Arif Ozyazici ${ }^{1}$ (i) Harun Bektas²}

${ }^{1}$ Department of Field Crops, Faculty of Agriculture, Siirt University, 56100, Siirt, Turkey. E-mail: semihacikbas@siirt.edu.tr. "Corresponding author. ${ }^{2}$ Department of Agricultural Biotechnology, Faculty of Agriculture, Siirt University, Siirt, Turkey.

ABSTRACT: Forage pea (Pisum sativum ssp. arvense (L.) Poir.) is an important legume crop for fresh and dry herbage production with high input costs as irrigation and fertilization. Selection and breeding of accessions for improved drought tolerance, water, and mineral uptake efficiency become a necessity, rather than a choice. This study evaluated a set of forage pea accessions for the seedling root system architecture diversity and seed reserve utilization, under controlled conditions. Eight cultivars and an elite breeding line were evaluated for the first time in a plexiglass system. The number and lengths of the roots in each depth zone $(0,5,10,15+\mathrm{cm})$ were evaluated and significant diversity was identified. The cultivar Livioletta had the highest number of roots and total root length. There was a significant correlation between seed weight, seed reserve utilization ratio, and root system vigor. Accessions with the highest seed reserve utilization had the highest total root length and numbers. Seedling root system vigor seems to be effective in predicting the fate of the accessions through maturity. The results suggested a possibility of "seedling root selection" for forage crop breeding.

Key words: root length, seed reserve utilization, forage pea, root architecture, lateral root.

Arquitetura do sistema radicular e relações de peso de sementes em ervilha forrageira (Pisum sativum ssp. arvense L. Poir.)

RESUMO: A ervilha forrageira (Pisum sativum ssp. arvense (L.) Poir.) é uma cultura leguminosa importante para a produção de forragem fresca e seca com alto custo de insumos como irrigação e fertilização. A seleção e reprodução de acessos para melhor tolerância à seca, eficiência de absorção de água e minerais tornam-se uma necessidade, ao invés de uma escolha. Este trabalho teve como objetivo avaliar um conjunto de acessos de ervilha forrageira quanto à diversidade da arquitetura do sistema radicular de mudas e utilização de reservas de sementes, em condições controladas. Oito cultivares e uma linha de melhoramento de elite foram avaliados pela primeira vez em um sistema de plexiglass. $O$ número e o comprimento das raizes em cada zona de profundidade $(0,5,10,15+\mathrm{cm})$ foram avaliados e uma diversidade significativa foi identificada. A cultivar Livioletta apresentou o maior número de raízes e comprimento total de raízes. Houve uma correlação significativa entre o peso da semente, a taxa de utilização de reserva de semente e o vigor do sistema radicular. Os acessos com a maior utilização de reserva de sementes tiveram o maior comprimento e número total de raízes. O vigor do sistema radicular de mudas parece ser eficaz em predizer o destino dos acessos até a maturidade. Os resultados sugerem a possibilidade de "seleção de raízes de mudas" para o melhoramento da cultura forrageira.

Palavras-chave: comprimento da raiz, utilização de reserva de sementes, ervilha forrageira, arquitetura da raiz, raiz lateral.

\section{INTRODUCTION}

Forage pea (Pisum sativum ssp. arvense L.) is an annual legume crop and can be planted as a primary, mixed or secondary crop for herbage or grain production. It is produced for cutting, green fertilizer, silage for ruminants, and grazing purposes. Forage pea has high protein, fiber, starch, soluble sugar, vitamin, and mineral content. The global annual green herbage production of forage pea is about 21 million tonnes on 2.7 million ha area, and 452.776 tonnes on about 24 thousand ha area in Turkey (FAOSTAT, 2019; TÜIK, 2020). It has wide adaptation potential and its ability to fix free nitrogen through nodules provide an advantage for the plants of the following season (KADIOGLU \& TAN, 2018). Besides, legumes can improve the physical conditions of the soil, increase soil fertility, provide better structure, reduce dependency on synthetic fertilizers, and allow better water holding capacity and aeration (YAVAS \& UNAY, 2018).

Cultivars with sustainable use of soil resources have been gaining attention due to reduced soil resource availability and climate change. Therefore, the root system is of great importance to obtain a high nutrient level and stable agricultural production (OBARA et al., 2014). Root architecture can be shaped based on resource availability, genetic

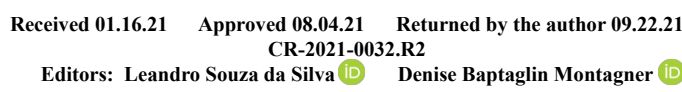


potential, and plasticity (GIEHL et al., 2012). The elongation and branching potential of the roots can vary, especially if the water and fertilizer are limited (BENGOUGH, 2012). One of the limiting factors for root growth is the level of stress. Under moderately stressed conditions, roots continue to grow, while under severe stress, root growth generally decreases due to limited carbon assimilation to below-ground.

Legumes need a well-developed root system in the seedling stage for early vigor, high biological and grain yield. An effective root system contributes to the water and mineral uptake under early drought stress (CHEN et al., 2017; SULIS et al., 2019). Besides, species/varieties with large root surface area are also advantageous in terms of nonmobile minerals (SILBERBUSH et al., 2013). Genetic variation between cultivars affects many important factors such as root surface area, secondary/lateral root growth angles (horizontal or vertical growth tendency), root biomass, and diameter. Climate change factors such as reduced water resources, and heat stress make it necessary to develop/select varieties with an advanced root system, and high and stable yield potential.

Analysis of variation in root systems has been neglected for many years due to technical limitations and high labor demand (LYNCH, 2007). Recently some studies on root development and architecture have been reported(WAINES \& EHDAIE, 2007; LYNCH, 2013; YAVAS \& UNAY, 2018). However, comprehensive studies are still limited to several model species. Although legume root systems have been extensively studied in terms of nodule formation (KOPITTKE et al., 2007; LATRACH et al., 2014), root architecture studies have been very limited especially in forage crops. Taproot length (MARSHALL, 1986), total root length (EVANS, 1973; LYNCH, 1995; CHEN et al., 2017), total lateral root length (BRAR et al., 1990; ZHAO et al., 2017), number of lateral roots (BRAR et al., 1990; CHEN et al., 2017), average root diameter (KRASILNIKOFF et al., 2003) and nodulation (KOPITTKE et al., 2007) were examined mostly in pulse crops. There were few reports on the root system evaluation of pea (Pisum sativum L.); however, we could not find any study with an in-depth analysis of the root system architecture (ZOBEL, 1974; MCPHEE, 2005). In addition to root traits, we also evaluated the effect of seed weight on root development. It is a well-known fact that genotypes with larger seeds, tend to develop larger seedlings (VALENCIA-DÍAZ et al., 2015); however, the effect of seed weight on seedling root development of individual plants in a given genotype is not previously reported. The effect of seed reserve utilization can be calculated indirectly by subtracting dry seed weight after seedling establishment from the original seed weight. The seed weight comparison aimed to see each genotype's potential to use storage reserves in the first weeks of development. Therefore, the aims of this study were; i) to determine the genetic variation of root system architecture in forage pea genotypes, ii) to determine the relationships between root architecture and seed reserve utilization, and iii) to demonstrate the possibilities of using the plate system in legume seedling root analysis.

\section{MATERIALS AND METHODS}

The study determined the seedling root system architecture diversity in forage pea (Pisum sativum ssp. arvense L. Poir.). Eight selected cultivars and an elite line from the Turkish gene pool were selected to represent the diversity of pea accessions in Turkey. The study was replicated two times in 2019 and 2020 under climate-controlled conditions in Siirt University, Faculty of Agriculture. The first experiment was established on March 28, 2019, while the second was established on March 2, 2020. Each experiment was continued for 15 days. In the study, Kirazl1, Taşkent, Özkaynak, Livioletta, Ulubatlı, Ürünlü, EK1, Gölyazı, and GAP Pembesi forage pea accessions were evaluated. Randomized complete block design with 3 replications and 10 plants per replication were followed in each season. Temperature and relative humidity were ranged between $25-27^{\circ} \mathrm{C}$ and $60-70 \%$, with a light/dark period of $14: 10 \mathrm{~h}$.

The effect of seed weight on the root system architecture within and between the accessions were evaluated by weighing each seed in the second season. Each dry seed was weighed individually with a precision scale before sowing and after the experiment (QIU et al., 1994). Seed weight differences as percent values were calculated to evaluate the role of seed reserve utilization on seedling root development.

Seeds were surface sterilized with $70 \%$ ethyl alcohol $\left(\mathrm{C}_{2} \mathrm{H}_{5} \mathrm{OH}\right)$ and $5 \%$ sodium hypochlorite (NaCIO) for 5 minutes and rinsed carefully with water. The seeds were imbibed in water for 24 hours to initiate uniform germination. The seeds were placed between two layers of germination papers $(40 \times 40 \mathrm{~cm})$ as two seeds per plate, and fitted with a plexiglass plate, and kept in a tub $\left(45^{\circ}\right.$ angle) filled with water. The plants were let to grow under complete dark conditions to eliminate photosynthesis. The experiments were terminated at 
the end of the $15^{\text {th }}$ day when roots reached the bottom of the germination paper.

Root samples were scanned at 600 DPI color scale with a hand-held scanner (Iscan Color Mini Portable Scanner). Root images were analyzed using ImageJ (imagej.nih.gov; RUEDEN et al., 2017) software. Roots were divided into four sub-sections and root traits in each sub-section were measured for higher precision (Table 1).

Analysis of Variance (ANOVA) was performed with Statistix 10 software (Analytical Software; Tallahassee, FL, USA) to measure variations within and between accessions. The data were tested for normality and homogeneity (Tables 2-4) and data collected for two years were combined. Variance groupings were done by the Least Significant Difference (LSD) test. Correlation coefficients between the traits were analyzed with the Pearson correlation test.

\section{RESULTS AND DISCUSSION}

Evaluation of root system traits can be conducted under controlled conditions such as hydroponics, aeroponics, pot, tube, growth pouches (WAINES \& EHDAIE, 2007; MANSCHADI et al., 2008; TOPP et al., 2013) or under field conditions such as shovelomics, trenching, rhizotron cameras, and x-ray (GREGORY et al., 2003; VAMERALI et al., 2012). Each technique has some advantages and disadvantages. When the aim is an in-depth screening of root traits, field methods are generally not feasible or completely reliable (SMIT et al., 2013). The modified cigar roll (ACIKBAS et al., 2021) technique (plexiglass) allowed us to evaluate every individual root with a high level of precision using image analysis. However, excessive manual labor is required for the image analysis of each seedling and each root/ section. A set of selected accessions of forage pea were evaluated for the first time at the seedling stage under controlled conditions for the evaluation of root system diversity.

The study was conducted for two consecutive seasons and the results of the first and second seasons were compared with variance analysis. There was no significant difference between the seasons; therefore, the mean values of the twoseason were combined. According to ANOVA results, there were significant differences in all traits $(\mathrm{P}<0.05)$. The highest NLR was at cv. Livioletta with 62.07 roots per plant, while the lowest was in cv. Özkaynak with 10.64 roots per plant. The mean value for the NLR was 29.31 roots per plant (Table 2). Total root length, TLRL, and TapRL values were the highest in Livioletta with $169.77,136.34$, and 33.45 $\mathrm{cm}$ per plant, respectively. The lowest values in TRL and TLRL were in Özkaynak with 39.79 and 20.01 $\mathrm{cm}$, and the shortest TapRL was in cv. Taşkent with $18.61 \mathrm{~cm}$ (Table 2). The mean values for the TLR, LRL, and TapRL were 92.35-, 68.03-, and $24.32 \mathrm{~cm}$

Table 1 - The names and abbreviations of the traits evaluated in the present study.

\begin{tabular}{|c|c|c|}
\hline Abbreviation & Trait Name & Related references \\
\hline NLR & number of lateral roots & MIA et al., 1996; CERITOGLU et al., 2020 \\
\hline TRL & total root length & CHEN et al., 2017 \\
\hline TLRL & total lateral root length & MIA et al., 1996; YE et al., 2018 \\
\hline TapRL & taproot length & KASHIWAGI et al., 2015 \\
\hline aTRL & average total root length & \multirow{2}{*}{ MERRILL et al., 2002} \\
\hline aLRL & average lateral root length & \\
\hline SWB & dry seed weight before sowing & \multirow[b]{2}{*}{ QIU et al., 1994} \\
\hline $\begin{array}{l}\text { SWE } \\
\text { SRU }\end{array}$ & $\begin{array}{l}\text { dry seed weight at the end of the study } \\
\text { seed reserve utilization }\end{array}$ & \\
\hline $0-5 \mathrm{RN}$ & total number of roots at $0-5$ & \multirow{8}{*}{$\begin{array}{l}\text { ORMAN-LIGEZA et al., 2014; CHEN et al., 2017; } \\
\text { CERITOGLU et al., } 2020\end{array}$} \\
\hline $5-10 \mathrm{RN}$ & total number of roots at $5-10$ & \\
\hline $10-15 \mathrm{RN}$ & total number of roots at $10-15$ & \\
\hline $15+\mathrm{RN}$ & total number of roots at $15+$ & \\
\hline $0-5 \mathrm{RL}$ & total lengths of roots at $0-5$ & \\
\hline $5-10 \mathrm{RL}$ & total lengths of roots at $5-10$ & \\
\hline $10-15 \mathrm{RL}$ & total lengths of roots at $10-15$ & \\
\hline $15+\mathrm{RL}$ & total lengths of roots at $15+$ & \\
\hline
\end{tabular}

Ciência Rural, v.52, n.6, 2022. 
Table 2 - Number and lengths of the total, lateral, and taproots of forage pea accessions for 2019 and 2020 average values.

\begin{tabular}{|c|c|c|c|c|}
\hline Accessions & NLR & TRL $(\mathrm{cm})$ & TLRL (cm) & TapRL $(\mathrm{cm})$ \\
\hline EK-1 (Elite line) & $19.39 \mathrm{de}$ & $86.24 \mathrm{c}$ & $58.47 \mathrm{c}$ & $27.77 \mathrm{~b}$ \\
\hline GAP Pembesi & $50.50 \mathrm{~b}$ & $136.92 \mathrm{~b}$ & $116.41 \mathrm{~b}$ & $20.50 \mathrm{de}$ \\
\hline Gölyazı & $30.75 \mathrm{c}$ & $85.33 \mathrm{c}$ & $61.28 \mathrm{c}$ & $24.00 \mathrm{bcd}$ \\
\hline Kirazlı & $33.21 \mathrm{c}$ & $97.94 \mathrm{c}$ & $73.02 \mathrm{c}$ & $24.92 \mathrm{bc}$ \\
\hline Livioletta & $62.07 \mathrm{a}$ & $169.77 \mathrm{a}$ & $136.34 \mathrm{a}$ & $33.45 \mathrm{a}$ \\
\hline Özkaynak & $10.64 \mathrm{f}$ & 39.79 e & $20.01 \mathrm{e}$ & $19.81 \mathrm{e}$ \\
\hline Taşkent & $20.08 \mathrm{de}$ & $60.26 \mathrm{~d}$ & $41.65 \mathrm{~d}$ & $18.61 \mathrm{e}$ \\
\hline Ulubatlı & 15.07 ef & $61.44 \mathrm{~d}$ & $39.29 \mathrm{~d}$ & 22.15 cde \\
\hline Ürünlü & $22.07 \mathrm{~d}$ & $93.47 \mathrm{c}$ & $65.81 \mathrm{c}$ & $27.66 \mathrm{~b}$ \\
\hline Average & 29.31 & 92.35 & 68.03 & 24.32 \\
\hline LSD & $6.236^{* *}$ & $18.078^{* *}$ & $16.326^{* *}$ & $4.088^{* *}$ \\
\hline$F$ value for the year effect & 0.001 & 1.13 & 1.56 & 0.28 \\
\hline
\end{tabular}

The difference between the means in the same group with the same letter is not statistically significant (LSD test, ${ }^{*}: \mathrm{P}<0.05$; $^{* *}: \mathrm{P}<0.01$ ), NLR: Number of lateral roots, TRL: Total root length, TLRL: Total lateral root length, TapRL: Taproot length.

per plant, respectively (Table 2). Accessions EK-1 $(4.31 \mathrm{~cm})$, Ürünlü $(4.20 \mathrm{~cm})$, Ulubatlı $(3.90 \mathrm{~cm})$, and Özkaynak (3.89) had the highest aTRL values. The highest values for the aLRL were in Ürünlü, EK-1, and Ulubatlı with $3.08 \mathrm{~cm}, 3.05 \mathrm{~cm}$, and $2.65 \mathrm{~cm}$, respectively (Table 3 ). When the NLR, TRL, and LRL are taken into consideration, the TRL and LRL averages were inversely proportional. The TapRL, TRL, and TLRL values obtained were not always in line with some studies on other legume crops, mostly pulses, which is expected due to the differences in genetic structure and growth conditions. Taproot length becomes critically important under limited water conditions (LINDH et al., 2014). Plant species with deep taproots can benefit from the moisture in the soil under drought conditions. It was observed that the varieties having the highest values in total and lateral root length constitute the lowest group for the number of roots and it is thought that when the NLR increased, the average length of each lateral

Table 3 - The mean values for aTRL, aLRL, SWB, SWE and SSUR of forage pea accessions for 2019 and 2020 average values.

\begin{tabular}{|c|c|c|c|c|c|}
\hline Accessions & aTRL (cm) & $\operatorname{aLRL}(\mathrm{cm})$ & SWB (g) & SWE (g) & SRU (\%) \\
\hline EK-1 (Elite line) & $4.31 \mathrm{a}$ & $3.05 \mathrm{a}$ & $0.215 \mathrm{a}$ & $0.110 \mathrm{a}$ & 48.8 \\
\hline GAP Pembesi & $2.75 \mathrm{~b}$ & $2.39 \mathrm{bc}$ & $0.206 \mathrm{ab}$ & $0.047 \mathrm{~b}$ & 77.2 \\
\hline Gölyazı & $3.07 \mathrm{~b}$ & $2.26 \mathrm{bc}$ & $0.153 \mathrm{de}$ & $0.050 \mathrm{~b}$ & 67.3 \\
\hline Kirazlı & $2.89 \mathrm{~b}$ & $2.21 \mathrm{bc}$ & $0.169 \mathrm{~cd}$ & $0.052 \mathrm{~b}$ & 69.2 \\
\hline Livioletta & $2.77 \mathrm{~b}$ & $2.24 \mathrm{bc}$ & $0.166 \mathrm{~cd}$ & $0.036 \mathrm{~b}$ & 78.3 \\
\hline Özkaynak & $3.89 \mathrm{a}$ & $2.26 \mathrm{bc}$ & $0.125 \mathrm{e}$ & $0.056 \mathrm{~b}$ & 55.2 \\
\hline Taşkent & $2.90 \mathrm{~b}$ & $2.00 \mathrm{c}$ & $0.133 \mathrm{e}$ & $0.056 \mathrm{~b}$ & 57.9 \\
\hline Ulubatlı & $3.90 \mathrm{a}$ & $2.65 \mathrm{ab}$ & $0.186 \mathrm{bc}$ & $0.120 \mathrm{a}$ & 35.5 \\
\hline Ürünlü & $4.20 \mathrm{a}$ & $3.08 \mathrm{a}$ & $0.183 \mathrm{c}$ & $0.091 \mathrm{a}$ & 50.3 \\
\hline Average & 3.41 & 2.46 & 0.171 & 0.069 & 59.97 \\
\hline LSD & $0.664^{* *}$ & $0.598^{*}$ & $0.022^{*}$ & $0.035^{*}$ & \\
\hline$F$ value for the year effect & 1.32 & 6.18 & - & - & - \\
\hline
\end{tabular}

The difference between the means in the same group with the same letter is not statistically significant $\left(\right.$ LSD test, ${ }^{*}: \mathrm{P}<0.05 ;{ }^{* *}: \mathrm{P}<$ 0.01) aTRL: average total root length, aLRL: average lateral root length, SWB: Seed weight before sowing, SWE: Seed weight at the end of the study, SRU: Seed reserve utilization. 
root gets shorter. This phenomenon can be partly explained by the carbon assimilate allocation. So, either a few long- or numerous short lateral roots, and these ideotypes are worth further consideration.

Seedling roots were divided into four growth zones (sections) as 0-5, 5-10, 10-15, and $15+\mathrm{cm}$ depths. A direct and precise comparison between the accessions was aimed. According to the results (Table 4), there were significant differences between the accessions for all sections. This allowed the observation and comparison of shallow or deep root growth habits at the seedling stage as well as the number and lengths of roots in each section (Table 4). Overall, for all root parameters, Livioletta and Gap Pembesi constituted the highest group at all depths, except $15+\mathrm{RN}$ and $15+\mathrm{RL}$. When the average values of root zones were compared, as the depth of the root increases, the number and length of the roots decreases. This is expected, due to the developmental stage of the lateral roots at the primary growth zone. The average taproot length was $24.32 \mathrm{~cm}$ and the range was between 18.61- and $33.45 \mathrm{~cm}$, and some accessions did not develop any laterals below $15+\mathrm{cm}$. This difference is thought to be due to differences in the genetic potential and phenological differences of lateral root initiation at seedling growth. Livioletta had a higher root number $(8.86$ roots per plant) and lengths $(8.90 \mathrm{~cm})$ at $15+\mathrm{cm}$ depth compared to average values of 1.83 per plant and $1.85 \mathrm{~cm}$, respectively (Table 4). In this context,
Livioletta established a well-developed root system at the seedling stage compared to others. The results of this study suggested significant genetic variation for rooting depth and distribution as well as a wide difference in the phenology of seedling root growth. A wide range of root lengths under various growth and experimental conditions were reported in previous studies (MARSHALL, 1986; EVANS, 1973; LYNCH, 1995; CHEN et al., 2017). Even though our results were in a similar range with previous reports on other legume species, it is not possible to make a direct comparison due to species diversity and differences in experimental design. The results presented are the first report of seedling root architecture diversity in forage pea.

The highest values for SWB were obtained in EK $(0.215 \mathrm{~g})$ and Gap Pembesi (0.206 g) and the mean SWB was $0.171 \mathrm{~g}$. After the $15^{\text {th }}$ day, when SWE was obtained, Livioletta had the highest seed reserve utilization ratio with $78.3 \%$, and the best results in the number and lengths of lateral roots, and total root lengths were also observed in this cultivar. It was followed by Gap Pembesi with a 77.2\% difference between SWB and SWE (Table 3). According to Pearson correlation analysis (Table 5), the SWE was in a negative correlation with most of the root growth parameters $(-0.12$ to -0.46$)$. These data support that the seed reserve utilization ratio positively affects early root development. A significantly negative correlation between the number $(-0.42)$ and length $(-0.38)$ of lateral roots with the SWE shows that

Table 4 - Mean values for the number and lengths of the roots in 0-5, 5-10, 10-15, and 15+ cm root zones for 2019 and 2020 average values.

\begin{tabular}{|c|c|c|c|c|c|c|c|c|}
\hline Accessions & $0-5 \mathrm{~cm} \mathrm{RN}$ & $0-5 \mathrm{~cm} \mathrm{RL}$ & $5-10 \mathrm{~cm} \mathrm{RN}$ & $5-10 \mathrm{~cm} \mathrm{RL}$ & $10-15 \mathrm{~cm} \mathrm{RN}$ & $10-15 \mathrm{~cm} \mathrm{RL}$ & $15+\mathrm{cm} \mathrm{RN}$ & $15+\mathrm{cm} \mathrm{RL}$ \\
\hline EK-1 (Elite line) & $8.52 \mathrm{c}$ & $31.48 \mathrm{~cd}$ & $5.92 \mathrm{~d}$ & $19.59 \mathrm{bc}$ & $3.74 \mathrm{bc}$ & $6.26 \mathrm{~b}$ & $1.21 \mathrm{~b}$ & $1.09 \mathrm{~b}$ \\
\hline GAP Pembesi & $22.07 \mathrm{a}$ & $63.86 \mathrm{a}$ & $19.07 \mathrm{a}$ & $38.02 \mathrm{a}$ & $8.21 \mathrm{a}$ & $12.96 \mathrm{a}$ & $1.14 \mathrm{~b}$ & $1.57 \mathrm{~b}$ \\
\hline Gölyazı & $13.75 \mathrm{~b}$ & $36.20 \mathrm{bcd}$ & $10.00 \mathrm{bc}$ & $16.30 \mathrm{bc}$ & $5.08 \mathrm{~b}$ & $6.67 \mathrm{~b}$ & $1.92 \mathrm{~b}$ & $2.11 \mathrm{~b}$ \\
\hline Kirazlı & $15.83 \mathrm{~b}$ & $45.43 \mathrm{~b}$ & $12.27 \mathrm{~b}$ & $22.48 \mathrm{~b}$ & $3.97 \mathrm{bc}$ & $4.16 \mathrm{bc}$ & $1.14 \mathrm{~b}$ & $0.96 \mathrm{~b}$ \\
\hline Livioletta & $24.79 \mathrm{a}$ & $75.05 \mathrm{a}$ & $18.57 \mathrm{a}$ & $38.21 \mathrm{a}$ & $9.86 \mathrm{a}$ & $14.19 \mathrm{a}$ & $8.86 \mathrm{a}$ & $8.90 \mathrm{a}$ \\
\hline Özkaynak & $7.29 \mathrm{c}$ & $16.48 \mathrm{e}$ & $2.71 \mathrm{e}$ & $2.56 \mathrm{~d}$ & $0.50 \mathrm{~d}$ & $0.35 \mathrm{c}$ & $0.14 \mathrm{~b}$ & $0.04 \mathrm{~b}$ \\
\hline Taşkent & $10.29 \mathrm{c}$ & $25.66 \mathrm{de}$ & $7.55 \mathrm{~cd}$ & $12.76 \mathrm{c}$ & $2.25 \mathrm{~cd}$ & $3.23 \mathrm{bc}$ & $0.00^{\mu}$ & $0.00^{\mu}$ \\
\hline Ulubatlı & $8.50 \mathrm{c}$ & $25.35 \mathrm{de}$ & $5.14 \mathrm{de}$ & $11.98 \mathrm{c}$ & $1.43 \mathrm{~cd}$ & $1.96 \mathrm{bc}$ & $0.00^{\mu}$ & $0.00^{\mu}$ \\
\hline Ürünlü & $9.43 \mathrm{c}$ & $37.70 \mathrm{bc}$ & $6.57 \mathrm{~d}$ & $19.45 \mathrm{bc}$ & $4.00 \mathrm{bc}$ & $6.69 \mathrm{~b}$ & $2.07 \mathrm{~b}$ & $1.98 \mathrm{~b}$ \\
\hline Average & 13.39 & 39.69 & 9.76 & 20.15 & 4.34 & 6.27 & 1.83 & 1.85 \\
\hline LSD & $3.192^{* *}$ & $11.438^{* *}$ & $3.096^{* *}$ & $8.701^{* *}$ & $2.641^{* *}$ & $5.434^{* *}$ & $3.415^{* *}$ & $4.465^{*}$ \\
\hline $\begin{array}{l}\text { F value for the } \\
\text { year effect }\end{array}$ & 0.016 & 0.93 & 1.75 & 0.11 & 0.24 & 2.23 & 3.57 & 3.44 \\
\hline
\end{tabular}

The difference between the means in the same group with the same letter is not statistically significant $\left(\right.$ LSD test, ${ }^{*}: \mathrm{P}<0.05 ;{ }^{* *}: \mathrm{P}<$ $0.01), \mu$ : The genotypes with no roots at $15+$ section are not included in the analysis of that section, RN: root number, RL: root length. 
Table 5 - Correlation coefficients ( $\mathrm{r}$ values) between forage pea accessions under controlled conditions for 2019 and 2020 average values.

\begin{tabular}{|c|c|c|c|c|c|c|c|c|c|c|c|c|}
\hline & TapRL & $\begin{array}{c}0-5 \mathrm{~cm} \\
\mathrm{RN}\end{array}$ & $\begin{array}{c}10-15 \\
\mathrm{~cm} \text { RN }\end{array}$ & $\begin{array}{c}15+ \\
\mathrm{cm} \text { RN }\end{array}$ & $\begin{array}{c}5-10 \\
\mathrm{~cm} \text { RN }\end{array}$ & $\begin{array}{c}0-5 \mathrm{~cm} \\
\mathrm{RL}\end{array}$ & $\begin{array}{r}10-15 \\
\mathrm{~cm} \text { RL }\end{array}$ & $\begin{array}{c}15+ \\
\mathrm{cm} \mathrm{RL}\end{array}$ & $\begin{array}{c}5-10 \\
\mathrm{~cm} \text { RL }\end{array}$ & NLR & TLRL & SWB \\
\hline $0-5 \mathrm{~cm} \mathrm{RN}$ & 0.13 & & & & & & & & & & & \\
\hline $10-15 \mathrm{~cm} \mathrm{RN}$ & 0.43 & 0.31 & & & & & & & & & & \\
\hline $15+\mathrm{cm} \mathrm{RN}$ & 0.49 & -0.03 & 0.47 & & & & & & & & & \\
\hline $5-10 \mathrm{~cm} \mathrm{RN}$ & 0.31 & 0.68 & 0.54 & 0.17 & & & & & & & & \\
\hline $0-5 \mathrm{~cm} \mathrm{RL}$ & 0.29 & 0.70 & 0.26 & 0.04 & 0.45 & & & & & & & \\
\hline $10-15 \mathrm{~cm} \mathrm{RL}$ & 0.36 & 0.27 & 0.90 & 0.30 & 0.41 & 0.28 & & & & & & \\
\hline $15+\mathrm{cm} \mathrm{RL}$ & 0.43 & -0.04 & 0.43 & 0.97 & 0.15 & 0.02 & 0.27 & & & & & \\
\hline $5-10 \mathrm{~cm} \mathrm{RL}$ & 0.43 & 0.50 & 0.51 & 0.18 & 0.84 & 0.47 & 0.51 & 0.15 & & & & \\
\hline LRN & 0.46 & 0.72 & 0.78 & 0.52 & 0.86 & 0.53 & 0.63 & 0.48 & 0.73 & & & \\
\hline LRL & 0.49 & 0.65 & 0.65 & 0.33 & 0.72 & 0.81 & 0.67 & 0.30 & 0.82 & 0.82 & & \\
\hline SWB & 0.24 & 0.18 & 0.19 & 0.10 & 0.06 & 0.35 & 0.26 & 0.09 & 0.25 & 0.18 & 0.38 & \\
\hline SWE & -0.17 & -0.28 & -0.34 & -0.12 & -0.46 & -0.25 & -0.28 & -0.10 & -0.39 & -0.42 & -0.38 & 0.51 \\
\hline
\end{tabular}

Taproot length (TapRL), number of roots at 0-5 $(0-5 \mathrm{RN}), 5-10(5-10 \mathrm{RN}), 10-15(10-15 \mathrm{~cm} \mathrm{RN}), 15+\mathrm{cm}(15+\mathrm{RN})$ and root lengths at 0-5 (0-5 RL), 5-10 (5-10 RL), 10-15 (10-15 RL), and 15+ cm (15+ RL), NLR: Number of lateral roots, TLRL: Total Lateral root length, SWB: Seed weight before sowing, SWE: Seed weight at the end of the study.

these two parameters are significantly affected by the seed reserve utilization ratio. Even though there were reports of the effect of hundred or thousand seed weight on root system development (HENDRIX, 1984; MARSHALL, 1986; GONZALEZ, 1993; MIAN \& NAFZIGER, 1994; MOSHATATI \& GHARINEH, 2012). Almost all of the literature was either about the germination rate or biomass. We could not find any reports evaluating individual seed weight and root architecture interactions. Our results suggested that accessions with lower seed reserve utilization ratios (Higher SWE) had the lowest root growth vigor. Early seedling establishment is a trait of interest under certain conditions (LÓPEZCASTAÑEDA et al., 1996). Hundred or thousand seed (kernel) weight is a well-known target; however, the seed reserve utilization ratio and its effect on earliness in root growth is an unexplored field. Evaluation of SWB and SWE ratio and root size might be a good indicator of the seedling vigor index, which needs further validation with different species and accessions under various growth conditions.

The average NLR was 29.31, and the range was between 10.64 - 62.07 roots per plant. BRAR et al. (1990) reported 12 to 27 secondary roots among 12 different forage plant species. The level of variation in the NLR is still not known for most of the forage legumes. There is a need for the evaluation of diverse sets (preferably germplasm core collections) of accessions to explore the genetic potential of the number and length of lateral roots. Previous reports on lateral root lengths on various legumes were between 2.3 to $44.3 \mathrm{~cm}$ (CHEN et al., 2017; LYNCH, 1995; ZHAO et al., 2017; BRAR et al., 1990). Secondary/lateral root lengths of pea (Pisum sativum L.) were reported between 34.4 and $120.2 \mathrm{~cm}$ (ZHAO et al., 2017), and on some forage legumes between 7.8 and $39.9 \mathrm{~cm}$ (BRAR et al., 1990). The length and distribution of lateral roots are the key indicators for nitrogen, phosphorus, and potassium uptake efficiency (WATT et al., 2013). Aiming specific root ideotypes might be a quick and reachable target. Identification of root phenotypic diversity would allow pedigree selection for breeding of specific above and below-ground characteristics. Therefore, when it comes to pedigree selection for root traits, there is no perfect accession, each accession may have a beneficial root architecture for a specific soil/rhizosphere condition (YORK et al., 2013).

Eight out of nine accessions evaluated are cultivars. All eight cultivars had previous yield and some quality parameters available. In the studies conducted on these accessions, when the plant height, hay yield, and crude protein ratios were evaluated, the highest values were in Livioletta (120.8-167.0 $\mathrm{cm}, 3808.8 \mathrm{~kg} / \mathrm{da}$, and $16.75 \%$, respectively) and Gap Pembesi $(134 \mathrm{~cm}, 3375.2 \mathrm{~kg}$, and 14.1-15.6\%, respectively), while the lowest values were in Taşkent 
(83.7-105 cm, $1057 \mathrm{~kg} / \mathrm{da}, 17.4 \%$ ) (SEYDOSOGLU et al., 2013; GELIR, 2018; TTSMM, 2018; ÖZDEMIR \& TAMKOC 2019). According to Variety Registration and Seed Certification Center (TTSMM, 2018) registry report, the Livioletta with the highest main stem length, green and dry herbage yield, emerged as the genotype with the best results. This cultivar followed by GAP Pembesi had the best results in root traits in our study. In this context, based on the results of this study and previous registry reports, accessions with early seedling vigor can be said to be superior to others. Seedling development vigor is a trait worth further consideration. While SWB may not highlight the role of seed weight on root development, the difference between SWB and SWE underlines the effect of seed reserve utilization ratio on seedling root development. These results suggested a further indepth analysis of multi-way interactions (dependency) between root traits. The root system should be evaluated and compared on a system scale, not by individual traits. However, there is still little knowledge on root system architecture, and it is hard to compare root system architectures with one another. The absence of such studies in forage crops and forage pea eliminates our comparison chance. The comparison and cost-benefit analysis of root ideotypes (LYNCH, 2013) would allow speed selection and breeding.

\section{CONCLUSION}

As a result of the seedling root system evaluations, the highest values for TRL, LRL, NLR, TapRL, aTRL, and aLRL were obtained in Livioletta. During the seedling development, this cultivar showed the highest performance in terms of root development. Among all the accessions evaluated, the highest seed reserve utilization ratio $(78.3 \%)$ and seedling root development $(169.77,136.34$, and 33.45 $\mathrm{cm}$ for TRL, TLRL, and TapRL, respectively) were also obtained on the same cultivar. Even though there is a considerable variation between the accessions at the seedling stage, further evaluations at different growth stages and under field conditions are needed for a better understanding of the response of each genotype to environmental fluctuations. This study suggested that there is a direct interaction between the seed weight and early root vigor as well as the seed reserve utilization ratio.

\section{ACKNOWLEDGEMENTS}

We are grateful to the Department of Agricultural Biotechnology, Faculty of Agriculture in Siirt University for allowing the use of laboratories.

\section{DECLARATION OF CONFLICT OF INTEREST}

The authors declare no conflict of interest.

\section{AUTHORS' CONTRIBUTIONS}

$\mathrm{SA}$ and $\mathrm{HB}$ designed and run the experiments, collected data, and wrote Ms draft; MAO contributed to writing, gave feedback. All authors read and approved the final manuscript.

\section{REFERENCES}

ACIKBAS, S. et al. The effect of salinity on root architecture in forage pea (Pisum sativum ssp. arvense L.) Legume Research, v.44, n.4, p.407-412, 2021. Available from: <https://10.18805/LR608 >. Accessed: May, 25, 2021. doi: 10.18805/LR-608.

BENGOUGH, A. G. Root elongation is restricted by axial but not by radial pressures: so what happens in field soil? Plant and Soil, v.360, n.1-2, p.15-18, 2012. Available from: <https://doi. org/10.1007/s11104-012-1428-8>. Accessed: Dec. 10, 2020. doi: $10.1007 / \mathrm{s} 11104-012-1428-8$.

BRAR, G. S. et al. Root development of 12 forage legumes as affected by temperature. Agronomy Journal, v. 82, p. 1024-1026, 1990. Available from: <https://doi.org/10.2134/ agronj1990.00021962008200050037x $>$ Accessed: Jan. 11, 2021. doi: 10.2134/agronj1990.00021962008200050037x.

CERITOGLU, M. et al. Root system variation of pulse crops at early vegetative stage. Notulae Botanicae Horti Agrobotanici Cluj-Napoca, v.48, n.4, p.2182-2197, 2020. Available from: $<$ https://doi.org/10.15835/nbha48412054>. Accessed: Jan. 05, 2021. doi: $10.15835 /$ nbha48412054.

CHEN, Y. et al. Characterizing root trait variability in chickpea (Cicer arietinum L.) germplasm. Journal of Experimental Botany, v.68, n.8, p.1987-1999, 2017. Available from: <https:// doi.org/10.1093/jxb/erw368> Accessed: Jan 07, 2021. doi: $10.1093 / \mathrm{jxb} / \mathrm{erw} 368$.

EVANS, P. S. Effect of seed size and defoliation at three development stages on root and shoot growth of seedlings of some common pasture species. New Zealand Journal of Agricultural Research, v.16, n.3, p.389-394, 1973. Available from: $<$ https://doi. org/10.2134/agronj1971.00021962006300030024x>. Accessed: Jan. 08, 2021. doi: 10.1080/00288233.1973.10421121.

FAO Statistical Database (FAOSTAT). Food and Agriculture Organization of the United Nations, 2019. Available from: <www. faostat.fao.org > . Accessed: May, 23, 2021

GELIR, G. Determination of silage quality characteristics of feed peas (Pisum sativum supsp arvense L.), triticale and mixtures grown in Diyarbakır conditions. Master thesis, Department of Animal Science Institute of Natural And Applied Sciences University Of Dicle, Diyarbakır. 2018.

GIEHL, R. F. et al. Localized iron supply triggers lateral root elongation in Arabidopsis by altering the AUX1-mediated auxin distribution. The Plant Cell, v.24, n.1 p.33-49, 2012. Available from: < https://doi.org/10.1105/tpc.111.092973>. Accessed: Dec. 01, 2020. doi: 10.1105/tpc.111.092973.

Ciência Rural, v.52, n.6, 2022. 
GONZALEZ, E. Effect of Seed Size on Germination and Seedling Vigor of Virola-Koschnyi Warb. Forest Ecology and Management, v.57, n.1-4, p.275-281, 1993. Available from: $<$ https:// doi.org/10.1016/0378-1127(93)90177-O>. Accessed: Dec. 21 , 2020. doi: 10.1016/0378-1127(93)90177-O.

GREGORY, P. J. et al. Non-invasive imaging of roots with high resolution X-ray micro-tomography. Plant Soil, p.255, 2003. Available from: <https://doi.org/10.1023/a:1026179919689>. Accessed: Dec. 23, 2020. doi: 10.1023/a:1026179919689.

HENDRIX, S. D. Variation in Seed Weight and Its Effects on Germination in Pastinaca-sativa L (Umbelliferae). American Journal of Botany, v.71, n.6, p.795-802, 1984. Available from: $<$ https://doi.org/10.1002/j.1537-2197.1984.tb14144.x>. Accessed: Nov. 25, 2020. doi: 10.2307/2443470.

KADIOĞLU, S.; TAN, M. Determination of Seed Yield and some characteristics of some forage pea lines and varieties in Erzurum conditions. Atatürk University Journal of the Agricultural Faculty, v.49, p.143-149, 2018. Available from: <https://doi. org/10.17097/ataunizfd.628404>. Accessed: Dec. 05, 2020. doi: 10.17097/ataunizfd.628404.

KASHIWAGI, J. et al. Scope for improvement of yield under drought through the root traits in chickpea (Cicer arietinum L.). Field Crops Research, v.170, p.47-54, 2015. Available from: $<$ https://doi.org/10.1016/j.fcr.2014.10.003>. Accessed: Dec. 31, 2020. doi: 10.1016/j.fcr.2014.10.003.

KRASILNIKOFF, G. et al. Variation in phosphorus uptake efficiency by genotypes of cowpea (Vigna unguiculata) due to differences in root and root hair length and induced rhizosphere processes. Plant Soil, v.251, p.83-91, 2003. Available from: <https://doi.org/10.1023/A:1022934213879>. Accessed: Nov. 01, 2020. doi: 10.1023/A:1022934213879.

KOPITTKE, P. M. et al. Toxic effects of low concentrations of $\mathrm{Cu}$ on nodulation of cowpea (Vigna unguiculata). Environmental Pollution, v.145, p.309-315, 2007. Available from: <https://doi. org/10.1016/j.envpol.2006.03.007>. Accessed: Jan. 01, 2021. doi: 10.1016/j.envpol.2006.03.007.

LATRACH, L. et al. Growth and nodulation of alfalfa-rhizobia symbiosis under salinity: electrolyte leakage, stomatal conductance, and chlorophyll fluorescence. Turkish Journal of Agriculture and Forestry, v.38, p.320-326, 2014. Available from: <https://doi.org/10.3906/tar1305-52>. Accessed: Jan. 09, 2021. doi: 10.3906/tar-1305-52.

LINDH, M. et al. Plant diversity and drought: The role of deep roots. Ecological Modelling, v.290, p.85-93, 2014. Available from: $<$ https://doi.org/10.1016/j.ecolmodel.2014.05.008>. Accessed: Jan. 12, 2021. doi: 10.1016/j.ecolmodel.2014.05.008.

LÓPEZ-CASTAÑEDA, C. et al. Seed and Seedling Characteristics Contributing to Variation in Early Vigor among Temperate Cereals, Crop Science, v.36 n.5, p.1257, 1996. Available from: $<\mathrm{https} / /$ doi. org/10.2135/cropsci1996.0011183X003600050031x>. Accessed: Jan. 14, 2021. doi: 10.2135/cropsci1996.0011183x003600050031x.

LYNCH, J. P. Root architecture and plant productivity. Plant Physiology, v.109, p.7, 1995. Available from: <10.1104/ pp.109.1.7>. Accessed: Jan. 28, 2020. doi: 10.1104/pp.109.1.7.

LYNCH, J. P. Roots of the second green revolution. Australian Journal of Botany, v.55, n.5, p.493-512, 2007. Available from:
$<$ https://doi.org/10.1071/BT06118> Accessed: jan 05, 2021. doi: 10.1071/BT06118

LYNCH, J. P. Steep, cheap and deep: an ideotype to optimize water and $\mathrm{N}$ acquisition by maize root systems. Annals of Botany, v.112, n.2, p.347-357, 2013. Available from: <https://doi.org/10.1093/ aob/mcs293 > . Accessed: Jan. 15, 2021. doi: 10.1093/aob/mcs293.

MANSCHADI, A. M. et al. Genotypic variation in seedling root architectural traits and implications for drought adaptation in wheat (Triticum aestivum L.). Plant and Soil, v.303, n.12, p.115-129, 2008. Available from: <https://doi.org/10.1007/ s11104-007-9492-1>. Accessed: Jan. 01, 2021. doi: 10.1007/ s11104-007-9492-1.

MARSHALL, D. L. Effect of seed size on seedling success in three species of Sesbania (Fabaceae). American Journal of Botany, v.73, n.4, p.457-464, 1986. Available from: <https://doi. org/10.1002/j.1537-2197.1986.tb12063.x>. Accessed: Jan. 01, 2021. doi: 10.1002/j.1537-2197.1986.tb12063.x.

MCPHEE, K. Variation for seedling root architecture in the core collection of pea germplasm. Crop Science, v.45, n.5, p.1758-1763, 2005. Available from: <https://doi.org/10.2135/ cropsci2004.0544>. Accessed: Jan. 13, 2021. doi: 10.2135/ cropsci2004.0544.

MERRILL, S. D. et al. Root length growth of eight crop species in haplustoll soils. Soil Science Society of America Journal, v.66, n.3, p.913, 2002. Available from: <https://acsess.onlinelibrary. wiley.com/doi/full/10.2136/sssaj2002.9130>. Accessed: Jan. 05, 2021. doi: $10.2136 /$ sssaj2002.9130.

MIA, M. W. et al. Root system structure of six food legume species: Inter and Intraspecific variations. Japanese Journal of Crop Science, v.65, n.1, p.131-140, 1996. Available from: <https://doi. org/10.1626/jcs.65.131>. Accessed: Jan. 12, 2021. doi: 10.1626/ jes.65.131.

MIAN, M. A. R.; NAFZIGER, E. D.; Seed Size and Water Potential Effects on Germination and Seedling Growth of Winter Wheat. Crop Science, v.34, n.1, p.169-171, 1994. Available from: $<$ https:// doi.org/10.2135/cropsci1994.0011183X003400010030x>. Accessed: Nov. 01, 2020. doi: 10.2135/cropsci1994.0011183X00 3400010030x.

MOSHATATI, A.; GHARINEH, M. Effect of grain weight on germination and seed vigor of wheat. International Journal of Agriculture and Crop Sciences, v.4, n.8, p.458460, 2012. Available from: <https://www.researchgate.net/ profile/Mh_Gharineh/publication /265805500_Effect_of_ grain weight on germination and seed vigor of wheat/ links/5690ab2308aec14fa557f0e9.pdf $>$. Accessed: Jan. 10, 2021.

OBARA, M. et al. Identification and characterization of quantitative trait loci for root elongation by using introgression lines with genetic background of Indica-type rice variety IR64. Plant Biotechnology Reports, v.8, n.3, p.267-277, 2014. Available from: <https://doi.org/10.1007/s11816-014-0320-9>. Accessed: Jan. 11, 2021. doi: 10.1007/s11816-014-0320-9.

ORMAN-LIGEZA, B. et al. Root system architecture. In: Morte A, Varma A (Eds), Root Engineering: Basic and Applied Concepts. Springer Heidelberg, New York. 2014. Available from: <https:// link.springer.com/chapter/10.1007/978-3-642-54276-3_3>. Accessed: Jan. 11, 2021. 
ÖZDEMIR, B.; TAMKOÇ, A. The Determination of Field Pea Lines Suitable for the Second Crop Production. Journal of Bahri Dagdas Crop Research, v.8, n.2, p.299-305, 2019. Available from: $<$ https://dergipark.org.tr/en/pub/bdbad/issue/51255/667236>. Accessed: Jan. 10, 2021.

QIU, J. et al. Seedling growth as affected by seed weight in common vetch. Agronomy Journal, v.86 p.251-255, 1994. Available from: $<$ https://doi.org/10.2134/agronj1994.00021962008600020008x>. Accessed: Jul. 10, 2021.

RUEDEN, C. T. et al. ImageJ2: ImageJ for the next generation of scientific image data, BMC Bioinformatics, v.18, p.529, 2017. Available from: <https://doi.org/10.1186/s12859-017-1934-z>. Accessed: Dec. 01, 2020. doi: 10.1186/s12859-017-1934-z.

SEYDOŞOĞLU, S. Determination of Yield and Yield Components of some Forage Pea (Pisum sativum L.) Genotypes in Diyarbakır Ecological Conditions. Turkish Journal of Nature and Science, v.2, n.2, p.21-27, 2013. Available from: < https://dergipark.org.tr/tr/ download/article-file/199051>. Accessed: Dec. 01, 2020.

SILBERBUSH, M. et al. Nutrient uptake and root system architecture modeling: Past and prospects for the future. In Plant Roots: The Hidden Half, Fourth Edition. CRC Press. p.385398, 2013. Available from: <https://pennstate.pure.elsevier.com/ en/publications/nutrient-uptake-and-root-system-architecturemodeling-past-and-pr>. Accessed: Dec. 01, 2020.

SMIT, A. L. et al. Root methods: a handbook. Springer Science \& Business Media. 2013. Available from: <https:// books.google.com.tr/books?hl=tr\&lr=\&id=bSjrCAAAQBAJ $\& o i=$ fnd \&pg $=$ PA2 \&dq=Root + methods $:+a+$ handbook $. \& o t s=$ pEGeQ7RVKZ\&sig=i84uI1Ijd7pxMyEQhFKKAsSTWs\&re dir_esc $=y \# v=$ onepage $\& \mathrm{q}=$ Root $\% 20$ methods $\% 3 \mathrm{~A} \% 20 \mathrm{a} \% 20$ handbook.\&f=false $>$. Accessed: Dec. 01, 2020.

SULIS, M. et al. Incorporating a root water uptake model based on the hydraulic architecture approach in terrestrial systems simulations. Agricultural and Forest Meteorology, v.269270, p.28-45, 2019. Available from: <https://doi.org/10.1016/j. agrformet.2019.01.034>. Accessed: Jan. 01, 2021. doi: 10.1016/j. agrformet.2019.01.034.

TOPP, C. N. et al. 3D phenotyping and quantitative trait locus mapping identify core regions of the rice genome controlling root architecture. Proceedings of the National Academy of Sciences of the United States of America, v.110, n.18, p.E1695-E1704, 2013. Available from: <https://doi.org/10.1073/pnas.1304354110>. Accessed: Dec. 01, 2020. doi: 10.1073/pnas.1304354110.

TÜİK. Plant production statistics. Available from: $<$ https://biruni tuik.gov.tr/medas $/$ ?kn=210\&locale=tr $>$. Accessed: Dec. 12, 2020.
VAMERALI, T. et al. Minirhizotrons in modern root studies. In S. Mancuso (Ed.), Measuring Roots. Berlin Heidelberg, Berlin: Springer-Verlag. 2012. Available from: <https://doi. org/10.1007/978-3-642-22067-8_17>. Dec. 12, 2020. doi: 10.1007/978-3-642-22067-8_17.

VARIETY REGISTRATION AND SEED CERTIFICATION CENTER (TTSMM). Republic of Turkey Ministry of Agriculture And Forestry, Forage Pea-2 Registration Report, 2018. Available from: $<$ https://www.tarimorman.gov.tr/BUGEM/TTSM/Belgeler/Duyuru\%20 Belgeleri $/ 2018 \% 20$ Tescil\%20Toplant $\%$ C4\%B1lar\%C4\%B1/tescil\%20 raporlar $\% \mathrm{C} 4 \% \mathrm{~B} 1 / \% \mathrm{C} 3 \% \mathrm{~A} 7 \mathrm{ay} \% \mathrm{C} 4 \% \mathrm{~B} 1 \mathrm{r} \% 20 \mathrm{mera} / \mathrm{yem} \% 20$ bezelyesi\%20-\%202.pdf>. Accessed: Jan. 01, 2021.

WAINES, J. G.; EHDAIE, B. Domestication and crop physiology: roots of green-revolution wheat. Annals of Botany, v.100, n.5, p.991-998, 2007. Available from: <https://doi.org/10.1093/aob/ mcm180>. Accessed: Jan. 11, 2021. doi: 10.1093/aob/mcm180.

VALENCIA-DÍAZ, $\mathrm{S}$ et al. How does the presence of endosperm affect seed size and germination?. Botanical Sciences, v.93, p.783789, 2015. Available from: <doi:10.17129/botsci.251>. Accessed: May, 23, 2021. doi: 10.17129/botsci.251.

WATT, M. et al. Root-based solutions to increasing crop productivity. In Plant roots: the hidden half, New York, NY: CRC Press. p. 21-1. 2013.

YAVAŞ, İ.; ÜNAY, A. Impact of Some Climate Change Parameters on Root, Nodule Formation and Nitrogen Fixation in Legumes. International Journal of Agriculture and Wildlife Science, v.4, n.2, p.270-278, 2018. Available from: <10.24180/ijaws.366386>. Accessed: Jan. 01, 2021. doi: 10.24180/ijaws.366386.

YE, H. et al. Genetic diversity of root system architecture in response to drought stress in grain legumes. Journal of Experimental Botany, v.69, n.13, p.3267-3277, 2018. Available from: <https://doi. org/10.1093/jxb/ery082\%20>. Accessed: Jan. 01, 2021. doi: 10.1093/ jxb/ery082.

YORK, L. M. et al. Integration of root phenes for soil resource acquisition. Frontiers in Plant Science, v.4, p.355, 2013. Available from: <https://doi.org/10.3389/fpls.2013.00355>. Accessed: Dec. 01, 2020. doi: 10.3389/fpls.2013.00355.

ZHAO, J. et al. A. Root architecture simulation improves the inference from seedling root phenotyping towards mature root systems. Journal of Experimental Botany, v.68, n.5, p.965982, 2017. Available from: <https://doi.org/10.1093/jxb/erw494>. Accessed: Jan. 05, 2021. doi: 10.1093/jxb/erw494.

ZOBEL, R. Root and nodule variability in peas. Pisum Newsletter, v.6, p.58-59, 1974. 